\title{
RANCANG BANGUN SISTEM E-MARKETING DALAM MENINGKATKAN PEMASARAN UMKM (USAHA MIKRO, KECIL DAN MENENGAH)
}

\author{
Dewi Yunita Sari ${ }^{1}$, Darsanto ${ }^{2}$, Ismail ${ }^{3}$ \\ ${ }^{1,2,3}$ Universitas Wiralodra, Jln. Ir. H. Juanda Km 3 Indramayu, Jawa Barat, Indonesia \\ dewiyunita245@gmail.com, aziz.faiz310105@gmail.com, arsip.ismaildahsyat@gmail.com
}

Diterima 29 Juni 2020, disetujui 05 Oktober 2020, diterbitkan 20 Oktober 2020

Pengutipan: Sari, D.Y, Darsanto, Ismail (2020). Rancang Bangun Sistem E-marketing dalam Meningkatkan Pemasaran UMKM (Usaha Mikro, Kecil dan Menengah). Gema Wiralodra, Vol 11, No 2, Hal 221-232, Oktober 2020

\begin{abstract}
ABSTRAK
Menurut Kepala Diskopdagin Kabupaten Indramayu Trisna Hendarin mengakui, pelaku UMKM (Usaha Mikro, Kecil dan Menengah) pemasarannya masih minim maka dilakukan pembuatan Rancang Bangun Sistem E-Marketing dalam Meningkatkan Pemasaran UMKM (Usaha Mikro, Kecil dan Menengah). Tujuan di adakan penelitian ini adalah untuk mengatasi masalah pemasaran yang dialami oleh industri rumahan dan memberikan kontribusi kepada kelompok UMKM (Usaha Mikro, Kecil dan Menengah) untuk menerapkan E-Marketing, serta meningkatkan pemasaran UMKM (Usaha Mikro, Kecil dan Menengah). Metodologi yang digunakan adalah studi literatur, pembuatan Flowchart atau alur sistem, Rancangan sistem, Diagram Use Case, pengujian sistem. Hasil penelitian ini yaitu sistem E-Marketing yang berbasis WEB dengan alamat situs http://umkmindramayu.com/
\end{abstract}

Kata Kunci : UMKM, E-Marketing, Kabupaten Indramayu

\begin{abstract}
According to the Head of the Indramayu Regency Diskopdagin Trisna Hendarin admits that the marketing of MSMEs (Micro, Small and Medium Enterprises) players is still minimal, so the E-Marketing System Design and Construction is carried out to Improve Marketing of MSMEs (Micro, Small and Medium Enterprises). The purpose of conducting this research is to solve the marketing problems experienced by the home industry and to contribute to the UMKM (Micro, Small and Medium Enterprises) group to implement E-Marketing, as well as to improve the marketing of MSMEs (Micro, Small and Medium Enterprises). The methodology used is literature study, making flowcharts or system flow, system design, use case diagrams, system testing. The results of this study are a WEB-based E-Marketing system with the website address http://umkmindramayu.com/
\end{abstract}

Keywords: UMKM, E-Marketing, Indramayu Regency

\section{PENDAHULUAN}

Kabupaten Indramayu adalah salah satu kabupaten yang ada di provinsi jawa barat yang memiliki kekayaan potensi bisnis yang bagus, memiliki daratan luas menjadikan Kabupaten Indramayu sebagai daerah pemasok produksi beras 
nasional. Berdasarkan bisnisukm.com selain beras, ada beberapa komoditas pertanian yang ada di Indramayu salah satunya adalah mangga, ada pula beberapa jenis hasil produk unggulan kabupaten indramayu yaitu batik indramayu, kerupuk, makanan dan minuman dari olahan buah mangga, ikan, dan udang (Widyaningrum and Bharata 2018)

Informasi yang dikutip dari laman https://indramayukab.go.id/ (https://indramayukab.go.id/ 2020) pada hari Jum'at 5 Juli 2019 Sebanyak 12 hasil produksi UMK (Usaha Mikro dan Kecil) itu dipasarkan di Alun-alun Kabupaten Indramayu, di antaranya makanan jenis abon sapi, abon kambing, abon teri, kerupuk kulit, kerupuk udang hingga olahan makanan dari buah mangga. Selain itu ada juga minuman sirup mangga dan jus mangga. Menurut Kepala Diskopdagin Kabupaten Indramayu Trisna Hendarin mengakui, pelaku UMK (Usaha Mikro dan Kecil) di Kabupaten Indramayu pemasarannya masih minim (Bisnisukm n.d.).

Masalah minimnya pemasaran hasil produksi UMKM di Kabupaten Indramayu adalah pemasaran masih secara tradisional dan kurangnya penggunaan internet atau media digital untuk di jadikan sarana sebagai promosi dan mengembangkan usahananya. Berdasarkan hasil studi Polling Indonesia yang bekerja sama dengan Asosiasi Penyelenggara Jasa Internet Indonesia (APJII), jumlah pengguna internet di Indonesia tumbuh 10,12 persen.

Menurut Sekjen APJII, Henri Kasyfi, survei ini melibatkan 5.900 sampel dengan margin of error 1,28 persen. Data lapangan ini diambil selama periode Maret hingga 14 April 2019.Hasilnya, dari total populasi sebanyak 264 juta jiwa penduduk Indonesia, ada sebanyak 171,17 juta jiwa atau sekitar 64,8 persen yang sudah terhubung ke internet. Menurut dia, kontribusi terbesar atas penetrasi internet di Indonesia berasal dari Pulau Jawa. Angka penetrasi di pulau ini mencapai 55 persen dari total keseluruhan. Dan di Pulau Jawa, Provinsi Jawa Barat menjadi wilayah dengan angka pengguna internet terbesar yang mencapai 16 persen. 


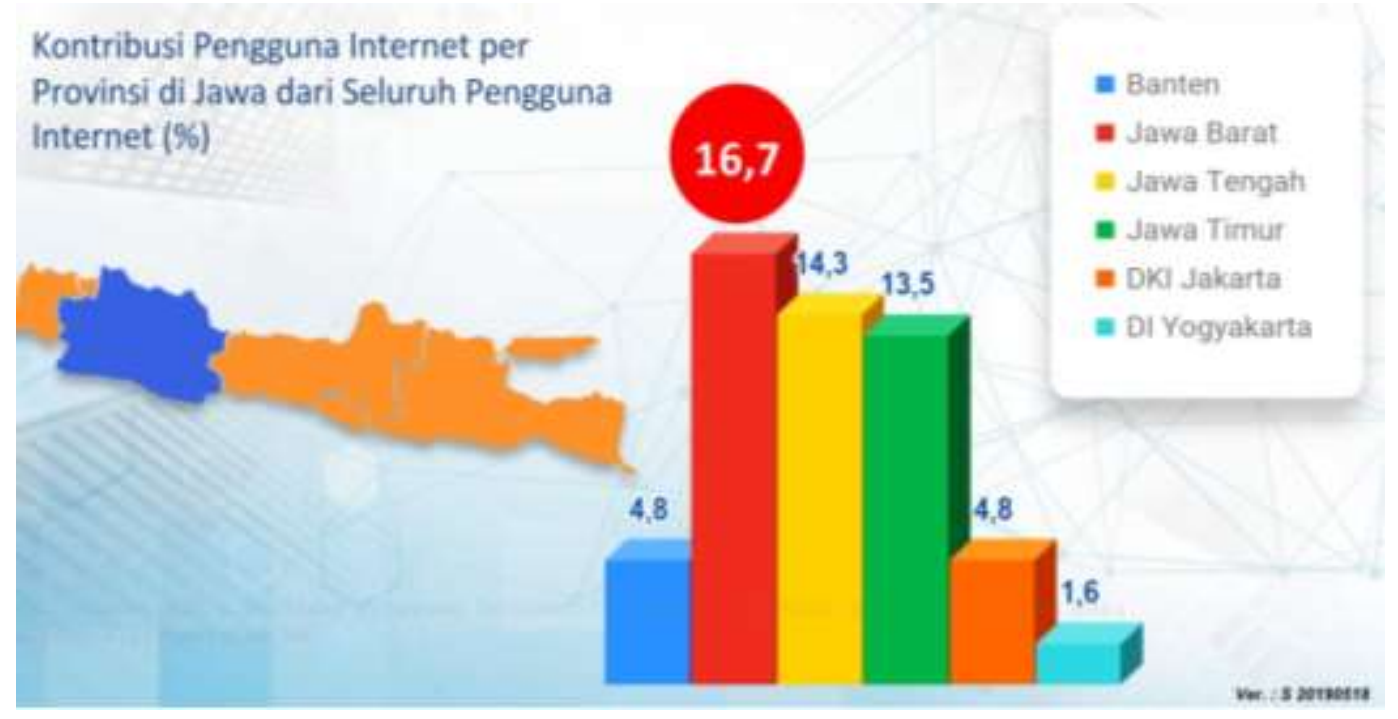

Gambar 1. Kontribusi penggunaan internet per provinsi di Jawa dari seluruh pengguna internet (APJII 2018)

Berdasarkan pengguna internet terbesar di pulau jawa adalah di provinsi jawa barat dan Potensi di kabupaten Indramayu yang begitu banyak, maka diperlukan strategi untuk meningkatkan pemasaran dan mempromosikan produksi UMKM kabupaten indramayu, dengan itu penulis melakukan program penelitian dengan membuat rancang bangun sistem dalam meningkatkan pemasaran UMKM (Usaha Mikro, Kecil dan Menengah) di Kabupaten Indramayu.

Menurut beberapa peneliti, pemasaran digital atau disebut juga $E$ Marketing di praktekkan dengan menggunakan sosial media dengan memanfaatkan jejaring sosial kepada pelaku UMKM (Purwana ES, Dedi, Rahmi, Aditya 2017). Penelitian lain menganalisis sistem pemasaran yang sedang berjalan di PT Nordic Lift Truck merancang suatu sistem pemasaran berbasis web (Budi et al. 2013). Peneliti lainnya pemasaran melalui media sosial adalah dengan menggunakan influencer marketing (Hariyanti and Wirapraja 2018). Penelitian (Yasmin, Tasneem, and Fatema 2015) meneliti tentang digital marketing dengan Iklan online Email Pemasaran Media sosial Pesan teks Pemasaran Afiliasi Optimisasi Mesin Pencari Bayar Per Klik. Peneliti (Bowden 2018) melakukan digital marketing dengan menggunakan sosial media. Peneliti (Setiyawan 2015) juga menggunakan sosial media untuk digital marketing. Peneliti lain (Kannan and Li 2017) juga menggunakan sosial media untuk digital marketing. Peneliti (Ištvanić, Milić, and Krpić 2017) melakukan digital marketing dengan 
menggunakan display advertising: google display network, customer journey, remarketing, remarketing, mobile marketing, social network marketing: facebook, instagram, twitter, pinterest, snapchat, linkedin, social media marketing for business; email marketing, discussion, conclusion. Peneliti (Jayaram, Manrai, and Manrai 2015) melakukan marketing teknologi dengan Web analytics, social media, customer analytics, digital campaigns and mobile applications. Peneliti (Ostlere 2019) juga meneliti Online Advertising, Email-marketing, Search Engine Optimization (SEP), Affiliate marketing, Social Media Marketing, Viral Marketing. Peneliti (Schwarzl and Grabowska 2015) juga melakukan marketing dengan Affiliate Marketing, E-Mail Marketing, Keyword-Advertising, Online Advertisin. Peneliti (Khan and Siddiqui 2013) juga melakukan digital marketing Mobile Phone, Online Videos, SEO - Google Rankings, SEO Keywords Tags Website Contents, Youtube, Social Media - Facebook, Social Media - linkedIn, Social Media-Twitter, Webinars, Pay-per-click, Google Analytics, Inlinks, Blogs, E-Newsletters, SEO - Title Tags, SEO - META Tags / descriptions. Peneliti (Mohan 2017) juga menggunakan Media, Digital and Mobile Internet dalam digital marketing. Peneliti (García et al. 2019) menggunakan Social Media Marketing on Social Networks untuk digital marketing

Menurut beberapa peneliti, pemasaran sistem dengan digital atau disebut $E$ Marketing digunakana karena efisiensi dari segi waktu, hemat biaya dan tenaga SDM, mudah mengaplikasikannya dan tidak sulit pengelolaannya dan mengontrolnya (Purwana ES, Dedi, Rahmi, Aditya 2017). Pemasaran berbasis digital digunakan untuk memperoleh konsumen, membangun preferensi mereka, promosi merek, memelihara konsumen, serta meningkatkan penjualan yang pada akhirnya meningkatkan profit. Digital marketing juga merupakan cara komunikasi dua arah yang dapat menimbulkan awareness dan engagement masyarakat terhadap produk dan merek tertentu (Kotler dan Philip 2004). Penggunaan EMarketing juga dapat memudahkan client memperoleh informasi produk dan jasa secara cepat dan efisien, sehingga memberikan kepuasan kepada pelanggan dengan menciptakan dan mempertahankan hubungan yang baik dengan client (Budi et al. 2013). 
Seiring dengan perkembangan zaman para pemasar pun wajib mengubah pola dan taktik pemasaran agar tetap mampu mengikuti perkembangan jaman dan mampu bersaing di pasar bebas dan para kompetitornya, salah sutunya adalah dengan memanfaatkan teknologi pemasaran digital untuk melengkapi strategi pemasaan konvensional yang telah ada (Hariyanti and Wirapraja 2018).

Beberapa penelitian diatas dapat menjadikan solusi untuk UMKM (Usaha Mikro, Kecil, dan Menengah) yang ada di Kabupaten Indramayu, oleh karena itu peneliti melakukan penelitian tentang Rancang Bangun sistem E-marketing untuk UMKM (Usaha Mikro, Kecil, dan Menengah) di Kabupaten Indramayu.

\section{METODE PENELITIAN}

\section{Prosedur kerja}

a. Studi literatur

Studi literatur dilakukan untuk mempelajari lebih dalam terkait bahasa pemrograman PHP yang digunakan pada sistem E-Marketing. Melakukan pengamatan terhadap UMKM yang ada di Indramayu.

b. Flowchart

Flowchart penelitian sistem E-Marketing dimulai dari menentukan konsep dari sistem, studi literatur dari pembuatan sistem, membuat rancangan sistem, membuat sistem dan uji coba sistem yang digunakan, jika uji coba berhasil maka sistem siap digunakan dan jika sistem terjadi permasalahan atau eror maka dilakukan pengecekan kembali pada sistem atau pengoreksian pada pembuatan sistem. Berikut ini adalah flowchart sistem E-Marketing:

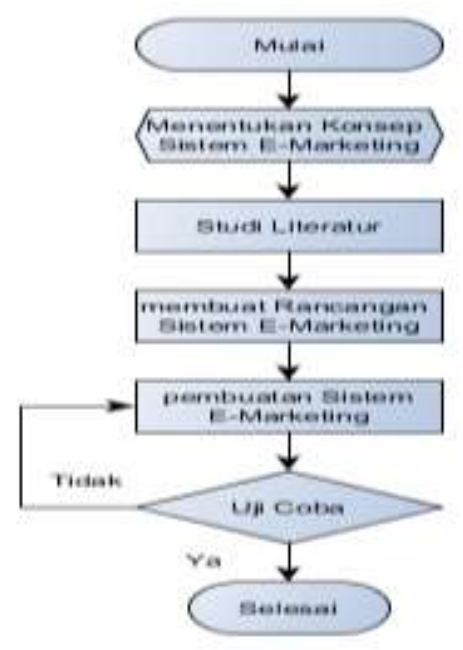

Gambar 1. Flowchart penelitian 
c. Rancangan sistem

Rancangan sistem E-Marrketing dibuat dengan melihat problem atau permasalahan yang ada pada UMKM di Indramayu, setelah adanya problem maka mendesign dan membuat sistem yang berbasis Web dengan menggunakan bahasa pemrograman PHP, sistem selesai maka dilakukan uji coba. Berikut rancangan sistem:

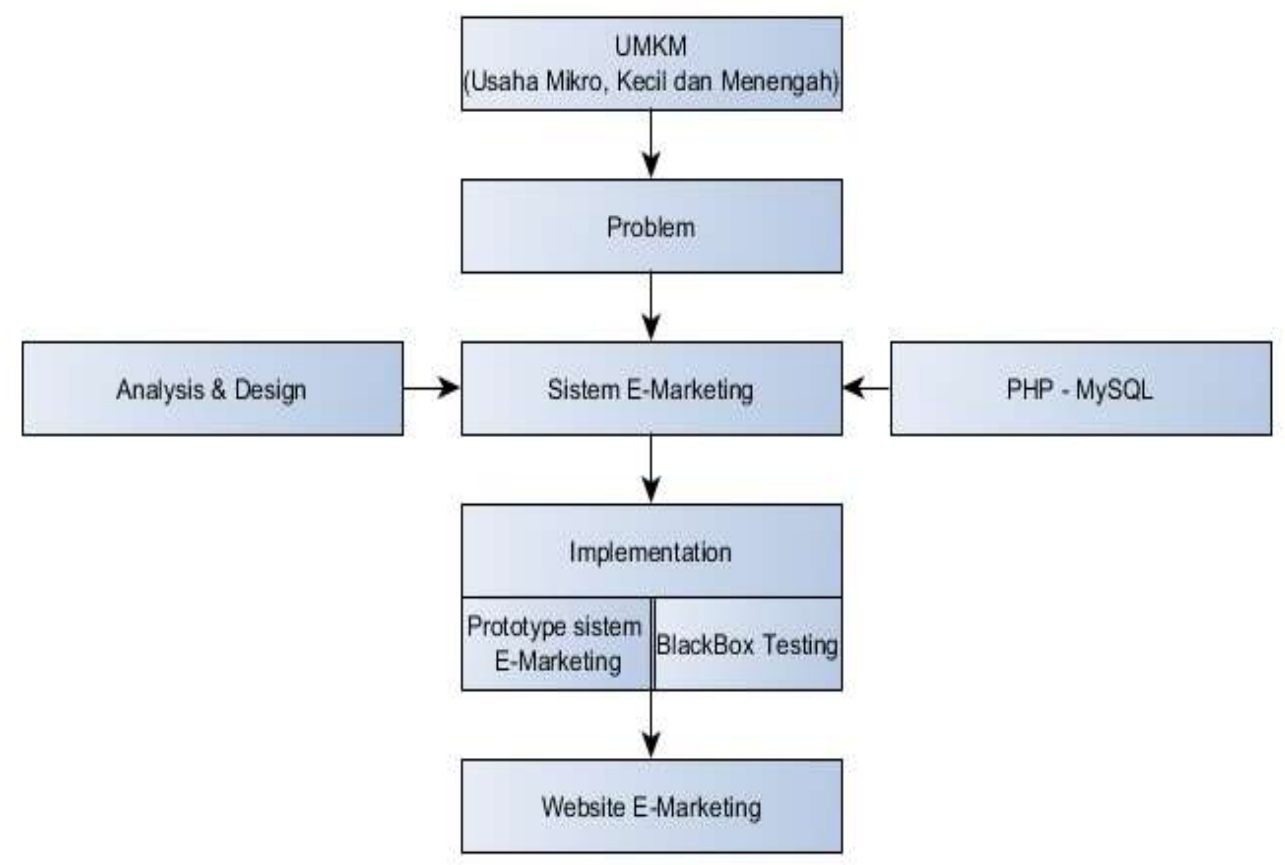

Gambar 2. Rancangan sistem E-Marketing

d. Diagram Use Case

Diagram use case mendeskripsikan sebuah interaksi pada sistem E-Marketing yaitu:

a) admin adalah untuk mengelola sistem, pelayanan dan pengiriman produk yang sudah dipesan.

b) Konsumen adalah dapat melihat katalog dan melakukan pemesanan

Berikut ini diagram use case pada sistem: 


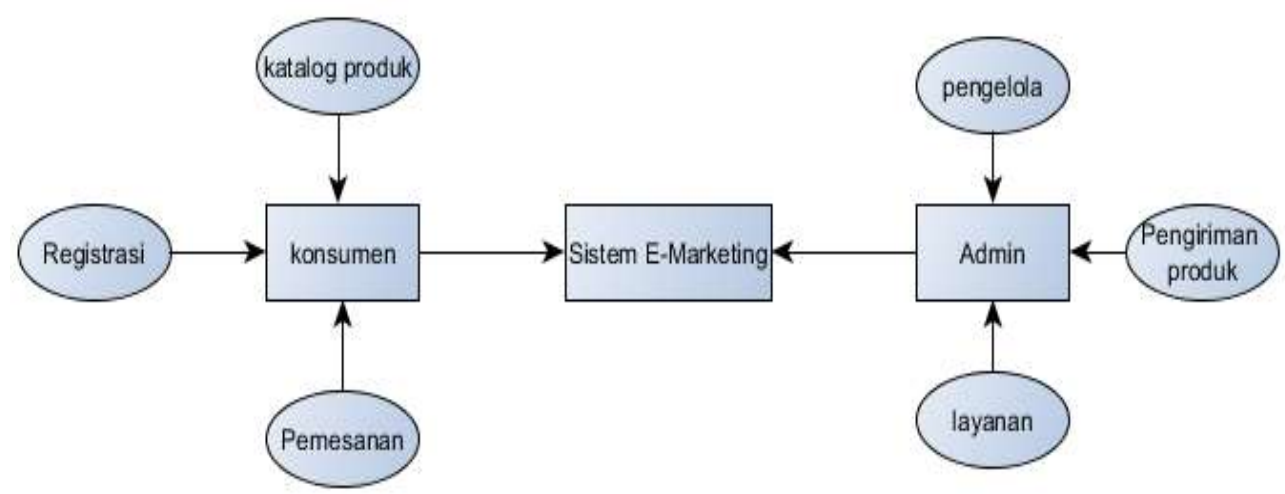

Gambar 3. Diagram use case

e. Penguji Sistem E-Marketing

Pengujian sistem dilakukan dengan cara melakukan proses jual beli dengan sistem E-Marketing antara penjual dan pembeli untuk mengetahui cara kerja sistem sudah sesuai apa belum, jika belum sesuai atau terjadi eror maka di lakukan perbaikan.

\section{HASIL PENELITIAN}

Hasil penelitian rancang bangun sistem E-Marketing dalam meningkatkan pemasaran UMKM (Usaha Mikro, Kecil dan Menengah) di Kabupaten Indramayu menghasilkan rancangan untuk sistem $\log$ in dan Sistem E-Marketing seperti gambar berikut:

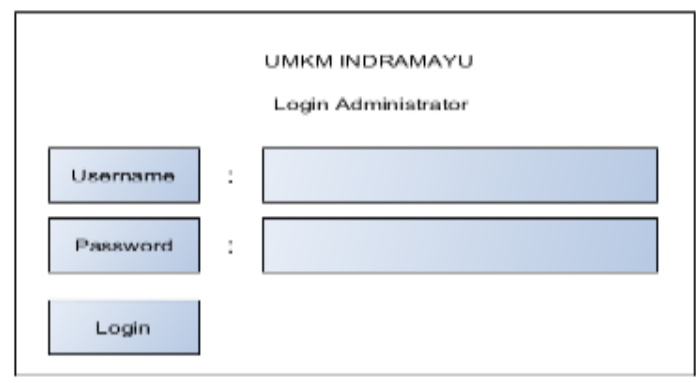

Gambar 4. Rancangan log in 


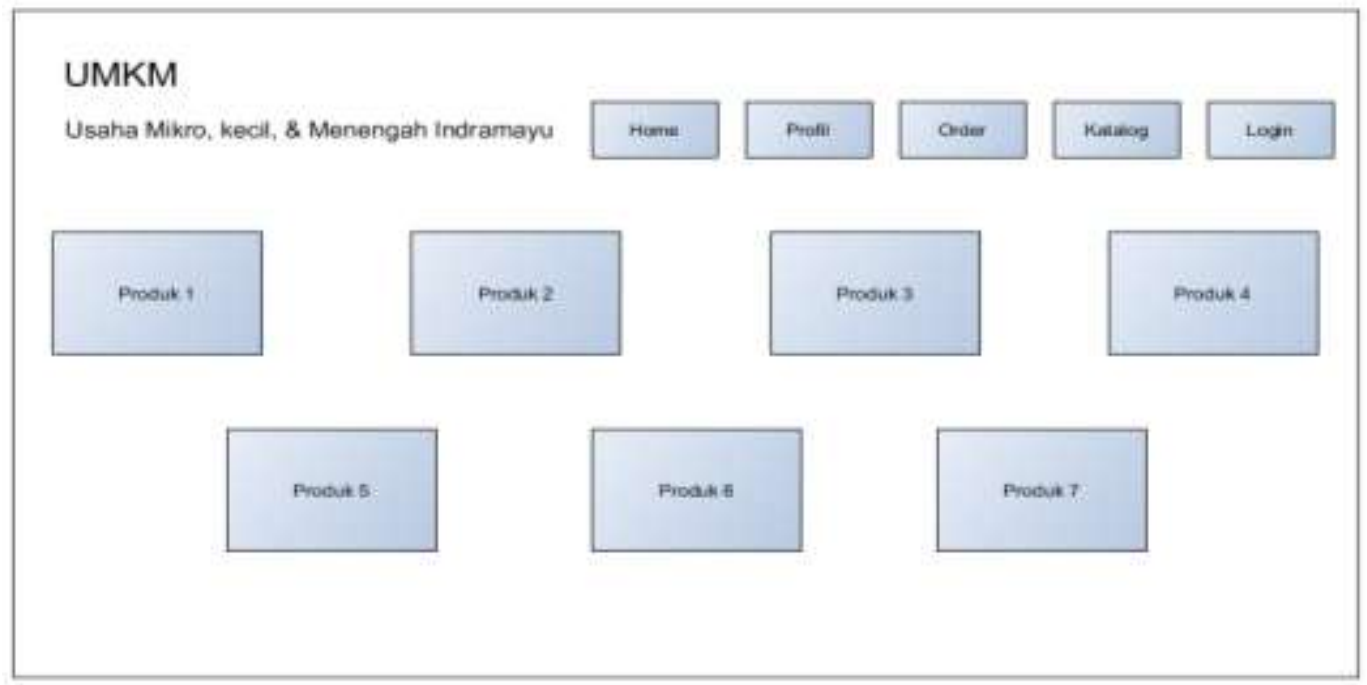

Gambar 5. Rancangan E-Marketing

Hasil Sistem E-Marketing dalam meningkatkan pemasaran UMKM (Usaha Mikro, Kecil dan Menengah) berbasis Web dengan alamat situs http://umkmindramayu.com/

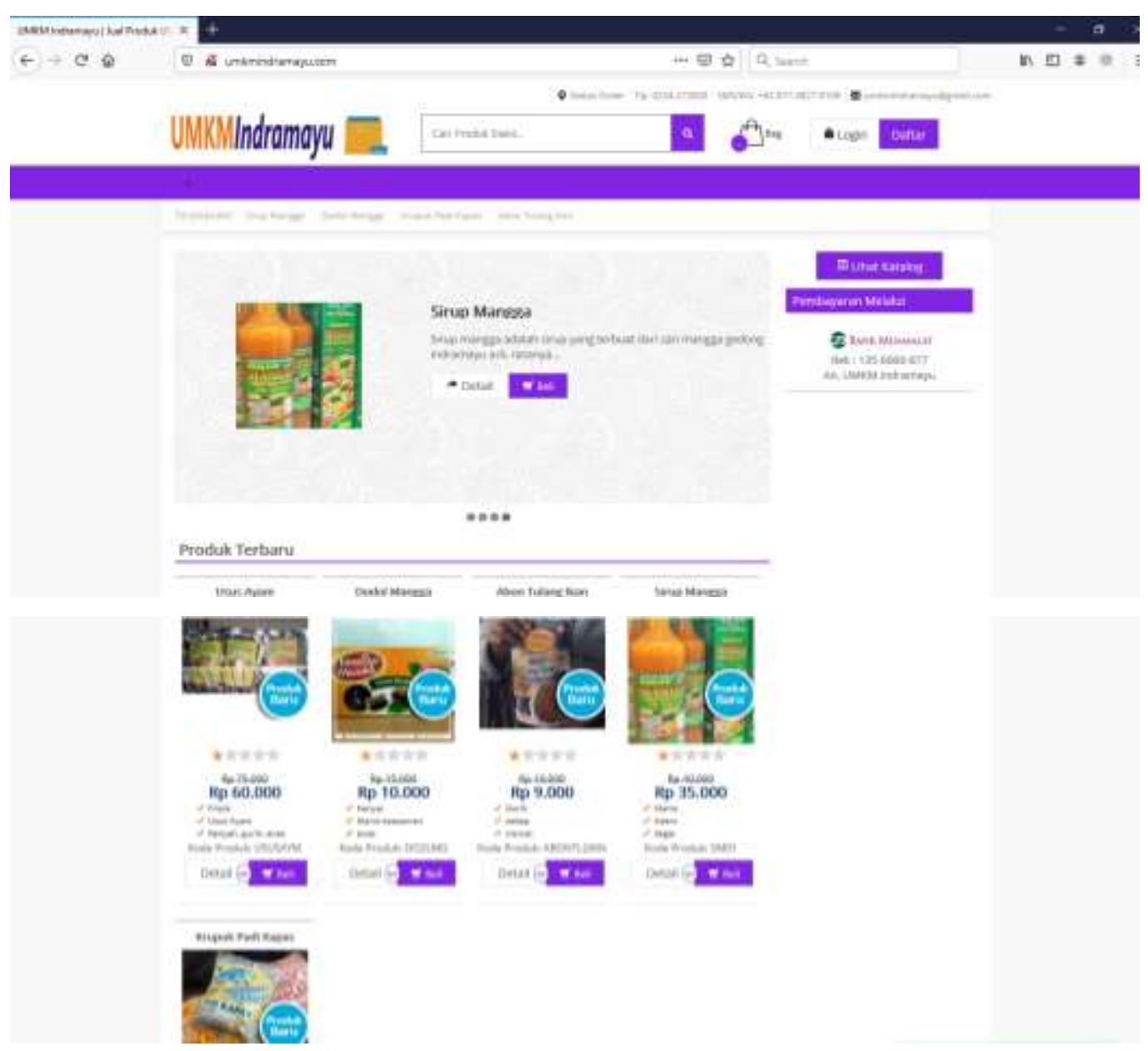




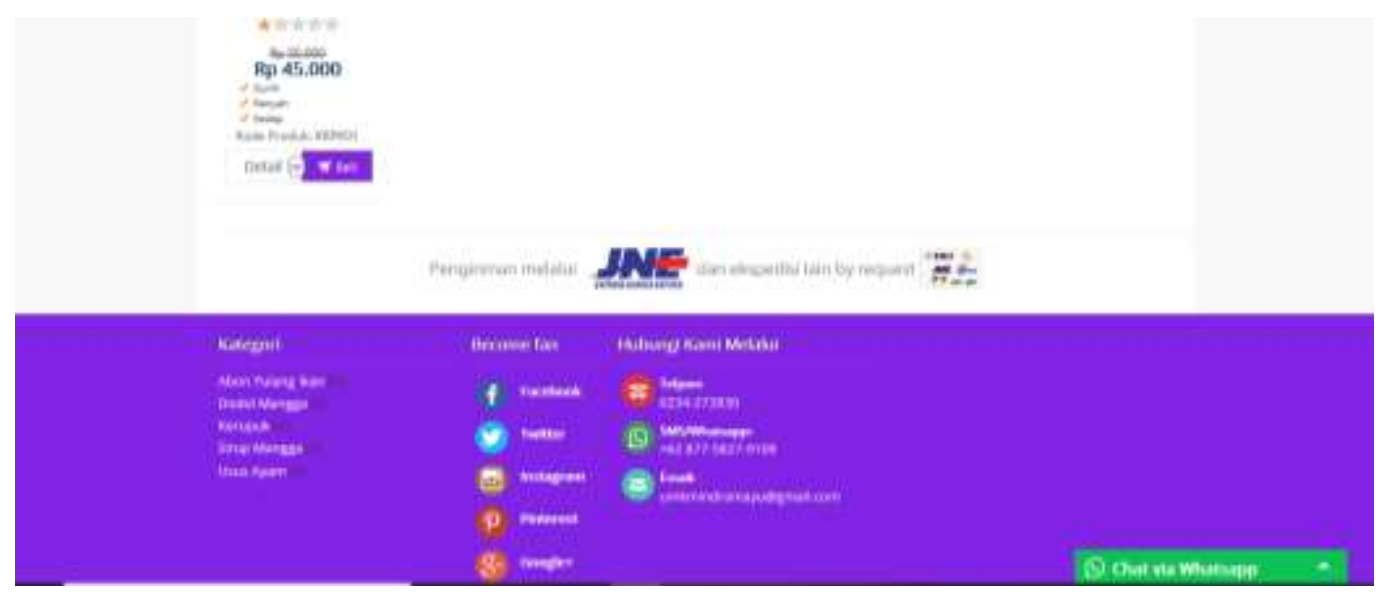

Gambar 6. Sistem E-Marketing

Sistem e-marketing untuk katalog, transaksi dan informasi mengenai produk UMKM (Usaha Mikro, Kecil dan Menengah).
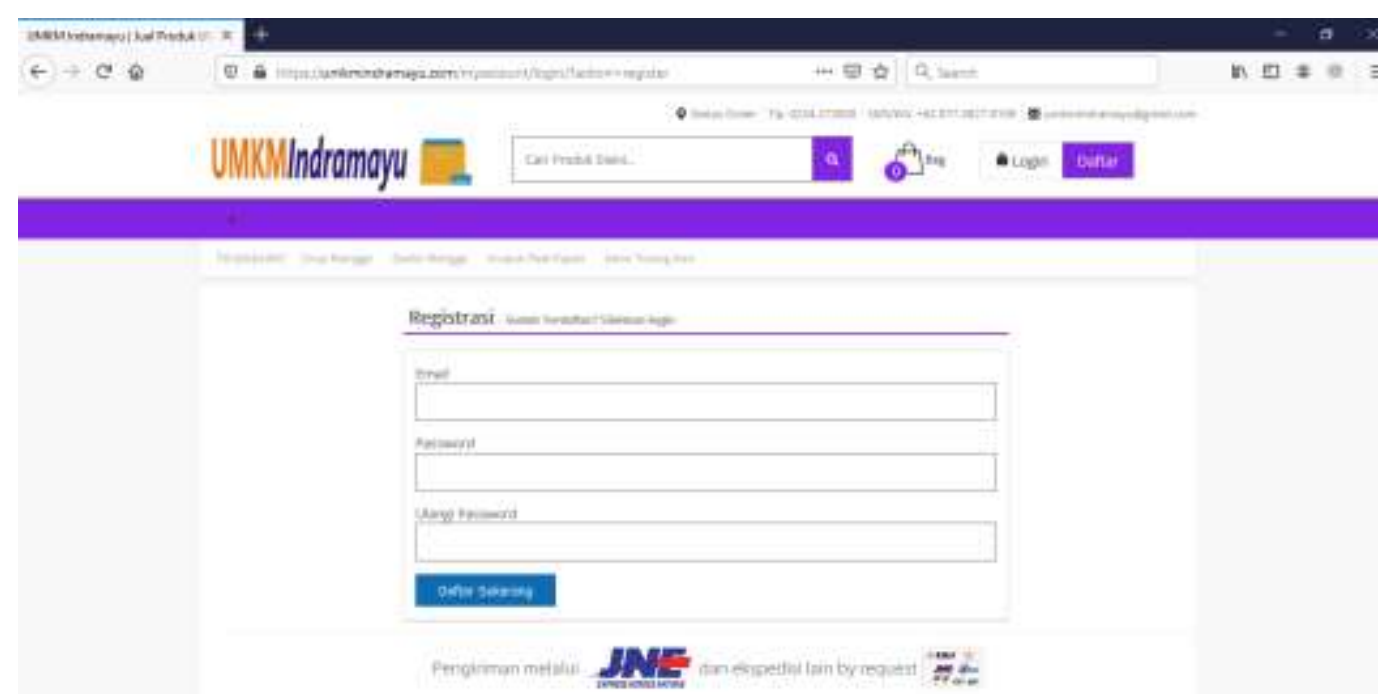

Gambar 7. Menu Daftar

Pada menu daftar ini dibuat untuk costumer yang mau membuat akun untuk bisa melakukan transaksi di Web UMKM Indramayu. 


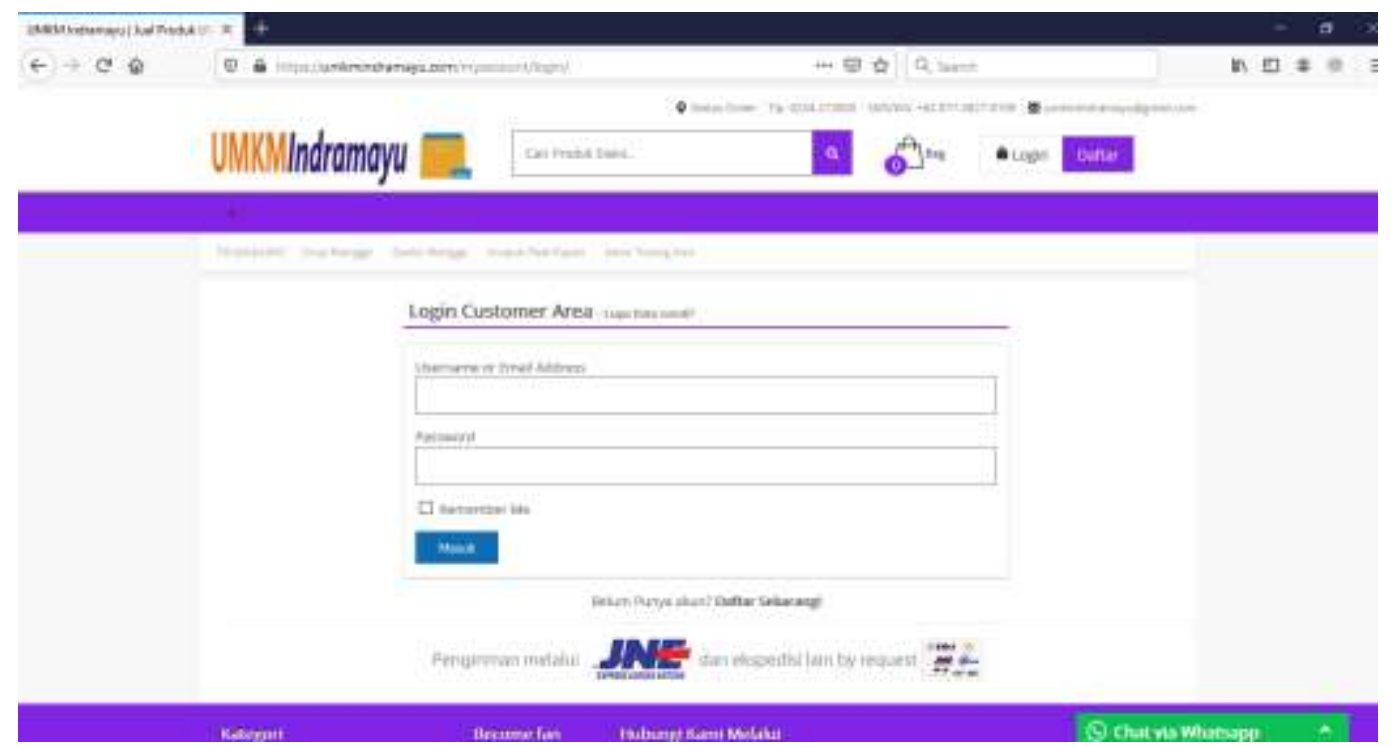

Gambar 8. Sistem Log In

Pada menu login terdapat login administrator dan login untuk costumer yang sudah mempunyai akun di UMKM Indramayu.

\section{KESIMPULAN}

Rancang bangun sistem e-marketing dilakukan rancangan sistem dengan membuat flowchart dan di buat sistem e-marketing yang berbasis Web dengan alamat situs http://umkmindramayu.com/ bertujuan untuk meningkatkan pemasaran UMKM (Usaha Mikro, Kecil dan Menengah).

\section{DAFTAR PUSTAKA}

APJII. 2018. "Penetrasi \& Profil Perilaku Pengguna Internet Indonesia." Apjii. www.apjii.or.id.

Bisnisukm. "Bisnisukm.” bisnisukm.com (September 20, 2007).

Bowden, J. 2018. "The Impact of Social Media Marketing Trends on Digital Marketing." Social Media Today , np, 17: 120-25.

Budi, Haris Setia, Wednes Pujiasmoro, Herjandi Wijaya, and Yuliyanti Yuliyanti. 2013. "Analisis Dan Perancangan Sistem E-Marketing Pada PT. Nordic Lift Truck." ComTech: Computer, Mathematics and Engineering Applications 4(1): 76.

García, Juan José López, David Lizcano, Celia M.Q. Ramos, and Nelson Matos. 2019. "Digital Marketing Actions That Achieve a Better Attraction and Loyalty of Users: An Analytical Study." Future Internet 11(6): 1-16. 
Hariyanti, Novi Tri, and Alexander Wirapraja. 2018. "Pengaruh Influencer Marketing Sebagai Strategi Pemasaran Digital Era Moderen (Sebuah Studi Literatur)." Jurnal Eksekutif 15(1): 133-46.

“Https://Indramayukab.Go.Id/.” 2020. https://indramayukab.go.id/.

Ištvanić, Marin, Dominika Crnjac Milić, and Zdravko Krpić. 2017. "Digital Marketing in the Business Environment." International Journal of Electrical and Computer Engineering Systems 8(2): 67-75.

Jayaram, Dureen, Ajay K. Manrai, and Lalita A. Manrai. 2015. "Effective Use of Marketing Technology in Eastern Europe: Web Analytics, Social Media, Customer Analytics, Digital Campaigns and Mobile Applications." Journal of Economics, Finance and Administrative Science 20(39): 118-32.

Kannan, P. K., and Hongshuang "Alice" Li. 2017. "Digital Marketing: A Framework, Review and Research Agenda." International Journal of $\begin{array}{llll}\text { Research in } & \text { 34(1): 22-45. }\end{array}$ http://dx.doi.org/10.1016/j.ijresmar.2016.11.006.

Khan, Fawad, and Kamran Siddiqui. 2013. "The Importance of Digital Marketing. An Exploratory Study to Find the Perception and Effectiveness of Digital Marketing amongst the Marketing Professionals in Pakistan." Journal of Information Systems \& Operations Management: 1-8. http://search.proquest.com/docview/1477205997?accountid=14744\%5Cnhttp ://fama.us.es/search*spi/i?SEARCH=18434711\%5Cnhttp://pibserver.us.es/gt b/usuario_acceso.php?centro=\$USEG\&centro=\%24USEG\&d $=1$.

Kotler dan Philip. 2004. Dasar-Dasar Pemasaran. Jakarta: Penerbit Erlangga.

Mohan, Dr. D. Madan. 2017. "Role of Digital Marketing Industry in India." Journal of Marketing Strategy (JMS) 5(2347): 371-77.

Ostlere, Rob. 2019. “Online Marketing.” The Actor's Career Bible (September): 783-92.

Purwana ES, Dedi, Rahmi, Aditya, Shandy. 2017. "Pemanfaatan Digital Marketing Bagi Usaha Mikro , Kecil , Dan Menengah ( Umkm ).” Jurnal Pemberdayaan Masyarakat Madani (JPMM) 1(1): 1-17.

Schwarzl, Susanne, and Monika Grabowska. 2015. "Online Marketing Strategies: The Future Is Here.” Journal of International Studies 8(2): 187-96.

Setiyawan. 2015. "THE ROLE OF DIGITAL AND SOCIAL MEDIA MARKETING IN CONSUMER BEHAVIOR.” Journal of Chemical Information and Modeling 53(9): 1689-99.

Widyaningrum, Premi Wahyu, and Wira Bharata. 2018. "Workshop Internet Dan 
Digital Marketing Untuk Meningkatkan Daya Saing Pada Kelompok Pengusaha Muda Ponorogo." Adimas: Jurnal Pengabdian Kepada Masyarakat 1(1): 1.

Yasmin, Afrina, Sadia Tasneem, and Kaniz Fatema. 2015. "Effectiveness of Digital Marketing in the Challenging Age: An Empirical Study." The International Journal of Management Science and Business Administration 1(5): 69-80. 